\title{
KARO PADĖTIES REŽIMAS LIETUVOS RESPUBLIKOJE 1919-1939 M. IR VISUOMENĖS POŽIŪRIS [ KARIUOMENĘ
}

\author{
Dr. Modestas Kuodys \\ Kauno IX forto muziejus
}

Anotacija. Straipsnyje siekiama ìvertinti, kiek nuolatinis karo padèties režimas Lietuvos Respublikoje (1919-1939 m.) paveikè visuomenès požiūrị ị kariuomenę. Aiškinamasi, kada ir kokie Ypatingu valstybès apsaugos istatu nustatytos tvarkos aspektai labiausiai trikdè kasdieni piliečiu gyvenima, kiek dèl to kaltinta kariuomene. Taip pat apibendrinamas Lietuvos politinès ir karinès valdžios požiūris i karo padèties režima, jo reikšmę valstybès ir jos ginkluotuju pajegu ịvaizdžiui.

Pagrindiniai žodžiai: Lietuvos Respublika, karo padètis, kariuomenè, visuomene, vidaus politika.

\section{IVADAS}

Lietuvos Respublikos kariuomenė per pirmajji neilgą savo autentiškos raidos etapą (1918-1940 m.) patyrė išties rimtų išbandymų. Tai - kovos už Nepriklausomybę vos ne išsyk su trimis galingais priešais, rusenantis ir vis karštomis kibirkštimis sužaižaruojantis teritorinis konfliktas dèl Vilniaus, Klaipėdos problema, ginkluoti pučai ir perversmai šalies viduje, nuolatinè karo padètis. Pastaroji tiesiog tapo kasdienybe, nes tęsèsi beveik dvidešimt metų - išskyrus du trumpus tarpsnius - 1926-ųjų antroje pusejje ir 1938-1939 m. Dar paradoksaliau atrodo tai, kad didžiąją to laikotarpio dalị, kai šalyje funkcionavo ypatingasis teisinis-administracinis režimas, daugiau ir mažiau aktyvių karo veiksmų Lietuvos teritorijoje arba jos pakraščiuose nevyko. Prasidejję 1919-ųjų pradžioje, jie faktiškai ilgam nurimo 1923-iaisiais. Esant tokiai situacijai, karo padèties ilgalaikiškumas tapo nenatūralus. Bet toks reiškinys - ne vien „lietuvių 
problema" ir ne vien praeities dalykas ${ }^{1}$. Panašių atvejų, kai išimtinè teisinè-administracinè būsena valstybèje tampa kone permanentiné, XX a., ypač jo antrosios pusès - „pokolonijinio“ pasaulio istorijoje, yra buvę nemažai. Kad ir koki iš tų atvejų imtume nagrinèti - kiekviename galime rasti universalių bruožų, daugiau ar mažiau jungiančių tam tikra prasme panašias ịvairių valstybių patirtis. Tai žinoti svarbu ne tik dèl lyginamųjų istorijos tyrimų perspektyvos, bet ir „praktiniais sumetimais“, ypač turint galvoje 2018 m. lapkričio pradžioje žiniasklaidoje pasirodžiusius pranešimus apie Lietuvos ketinimus artimiausioje ateityje atnaujinti karo padèties reglamentaciją ${ }^{2}$. Be to, bent jau formaliu pretekstu atsigręžti ì praeitị ir darsyk įvairiais rakursais pažvelgti i ilgalaikio ypatingojo režimo Lietuvoje fenomeną gali tapti ir Lietuvos Respublikos bei jos ginkluotujuc pajègų susikūrimo šimtmečio sukaktis. Tai gera simbolinė proga ne tik platesniesiems visuomenès sluoksniams, bet ir istorikų bendrijai tam tikra prasme iš naujo permąstyti esminius, atrodytų, jau gana nuodugniai ištyrinètus minèto laikotarpio faktus, reiškinius ir jų vertinimus. Karo padeties „klausimas“ Lietuvoje (1919-1939 m.) taip pat priklauso kategorijai temų, kurias istorikai jau yra nemažai ir įvairiapusiškai „vartę“, bet kurios vis dar kelia diskusijas. Glaustai apžvelgiant istoriografiją aptariamąja tema, reikètų pažymèti keletą esminių dalykų.

Gana daug dèmesio karo padèties temai, tiesa, tendencingais, pro-

1 Galima pateikti kone „vakarykštės dienos“ pavyzdžių. Antai daugelis $2011 \mathrm{~m}$. Arabų pavasario paliestų Artimųjų Rytų ir Šiaurès Afrikos šalių metų metus iki tol gyveno sukaustytos vienokios ar kitokios ypatingosios padèties „ledo“. (Glaustą, bet konceptualią ryškesnių atvejų lyginamąją analizę žr.: Zwitter, A. The Arab Uprising. State of Emergency and Constitutional Reform, http://www.airuniversity.af.mil/Portals/10/ASPJ_French/ journals_E/Volume-05_Issue-2/Zwitter_e.pdf). Net NATO narejee Turkijoje po nepavykusio bandymo 2016 m. liepą nuversti prezidentą Redžepą Taypą Erdoganą ịvesta nepaprastoji padètis paskui buvo pratęsta septynis kartus iš eilès ir galiojo iki $2018 \mathrm{~m}$. vidurio (Кёйлю Х., Елкина А. Что произошло в Турции за время действия чрезвычайного положения?, https://p.dw.com/p/31bPM). O tų pačių metų pabaigoje po Rusijos karinių jūrų pajègų surengto išpuolio Kerčès sąsiauryje Ukraina, siekdama bent jau simbolinio politinio demaršo, per žiniasklaidos priemones plačiai išgarsino dekretą dèl karo padèties ịvedimo dalyje savo teritorijos (Martial law expires in Ukraine, https://www. reuters.com/article/us-ukraine-crisis-russia-martiallaw/martial-law-expires-in-ukraineidUSKCN1OP0QV).

2 Atnaujinamas karo padeties ịstatymas, https://www.lzinios.lt/lietuva/atnaujinamaskaro-padeties-istatymas/251974. 
pagandiniais sumetimais, buvo skiriama sovietmečiu. Nuo 1990-ųjų, išlaisvėjus intelektualinei atmosferai, daugelis tų privalomų dogmatiškų vertinimų buvo peržiūrèti, esmingai pakoreguoti. Tačiau ypatingojo teisinio-administracinio režimo gana ilgai beveik nemėginta specialiai kompleksiškai tyrinèti. Dažniausia analizuoti paskiri jo aspektai, o pati karo padètis tarsi likdavo kontekste. Solidų indèlị, praplètusi šio specifinio reiškinio suvokimą, pirmiausia konstitucionalizmo plotme, paliko Mindaugas Maksimaitis ${ }^{3}$. Autoritarinès santvarkos ir karo padèties sąveiką savo monografijose apie prezidentą Antaną Smetoną konceptualiai įvertino istorikai Liudas Truska ${ }^{4}$ ir Alfonsas Eidintas ${ }^{5}$. Tvirtą pamatą Lietuvos kariuomenès istoriografijoje padejo Jonas Vaičenonis ${ }^{6}$. Tai iš esmès paskatino kelių papildomų tyrimų atsiradimą. Pirmasis priklauso šių eilučių autoriui, savo disertacijoje pabandžiusiam apibendrinti karo padèties funkcionavimą Lietuvoje 1919-1940 m. ${ }^{7}$, o antrasis - Andrejui Stoliarovui, nuodugniai išnagrinejjusiam karinių teismų sistemą ${ }^{8}$. Kol kas pats naujausias darbas, kuriame ị karo padètị atsigręžiama kaip ị vieną iš veiksnių, lèmusių Lietuvos politinès ir karinès vadovybès santykius, yra Kęstučio Kilinsko daktaro disertacija ${ }^{9}$.

Taigi, mus dominančios temos istoriografija yra gana gausi ir įvairi, tačiau tam tikrų probleminių aspektų plètojimo ir interpretacijų galimybès, atrodo, dar nevisiškai išsemtos. Šis straipsnis - tai glaustas bandymas

3 Paminèsime tik kai kuriuos darbus iš îspūdingos profesoriaus bibliografijos: Maksimaitis, M. Tautininkų fašistinè diktatūra, Buržuazinès diktatūros Lietuvoje valstybiniai teisiniai aspektai. Vilnius, 1976; Maksimaitis, M. Teisinès valstybès modelis, Mykolo Römerio mokslas apie valstybę. Vilnius, 1997; Maksimaitis, M. Lietuvos teisès šaltiniai 1918-1940 metais. Vilnius, 2001; Maksimaitis, M. Lietuvos konstituciju istorija (XX a. pirmoji pusé). Vilnius, 2005.

4 Truska, L. Antanas Smetona ir jo laikai. Vilnius, 1996.

5 Eidintas, A. Antanas Smetona: Politinés biografijos bruožai. Vilnius, 1990; Eidintas, A. Antanas Smetona ir jo aplinka. Vilnius, 2012.

6 Vaičenonis, J. Lietuvos kariuomenè valstybès politinio gyvenimo verpetuose (19271940). Vilnius, 2004.

7 Kuodys, M. Karo padeties režimas Lietuvos Respublikoje 1919-1940 m. Daktaro disertacija. Vytauto Didžiojo universitetas, 2009.

8 Stoliarovas, A. Lietuvos Respublikos kariné justicija 1919-1940 m. Kaunas, 2014.

9 Kilinskas, K. Civilinès ir karines valdžios sąveika Lietuvoje 1918-1940 m. Daktaro disertacija. Vilniaus universitetas, 2018. 
pateikti keletą tokių perdèm nepretenzingų „proginių“ pamąstymų. Bet pirmiausia norètųsi atskirai pakomentuoti iš pažiūros gana keistoką jo pavadinimą. Toks jis pasirinktas sąmoningai, autoriui iškèlus hipotetinę prielaidą, kad visuomenès požiūris ị karo padètị ir kariuomenę, kaip šị ypatingajj režimą turejjusią administruoti instituciją, dèl tam tikrų juridinès ir faktinès situacijos nesutapimų nagrinejjamu laikotarpiu kai kada galejo gana aiškiai skirtis. Trivialiai tariant, jei karo padèties egzistavimas, jos nustatyta tvarka ir keldavo kažkoki nepasitenkinimą piliečiams, dèl to jie nebūtinai visą „kaltę“ pirmiausia versdavo kariuomenei, nes kariškių įsitraukimas ị ypatingojo režimo nuostatų igyvendinimą laikui bėgant labai sumenko. Kaip tik ši niuansą ir norima akcentuoti. Todèl straipsnio tikslas suformuluotas taip: ìvairių istorinių šalinių analizès ir sintezès būdais ịvertinti, kiek ir kaip nuolatinis karo padèties režimas galejo paveikti Lietuvos visuomenès požiūrị ị kariuomenę. Kad tai būtų galima igyvendinti, numatyta atlikti du uždavinius:

1) Išanalizuoti, kokie karo padèties tvarkos aspektai kèlè daugiausia nepasitenkinimo civiliams ir kiek dèl to kaltinti kariškiai.

2) Apibendrinti Lietuvos politinès ir karinès vadovybès reakciją $\mathfrak{i}$ karo padèties iššūkius kariuomenès reputacijai.

Deklaravus tokius kognityvinius siekius, atrodo, būtina iš karto sąžiningai pripažinti, kad jų igyvendinimo rezultatai tam tikra prasme bus riboti, t. y. daliniai. Pirmiausia dèl to, kad ilgalaikès karo padèties poveikio Lietuvos kariuomenès ịvaizdžiui ir reputacijai ịvertinimas nelabai gali būti kitoks, kaip tik hipotetinis, orientacinis, atviras diskusijoms, nes sunku rasti instrumentą, leidžiantị objektyviai išmatuoti to poveikio mastą ar laipsnị. Nèra jokios šabloninès kriterijų skalès, galinčios pasitarnauti pavyzdžiu, nèra sutarta ir dèl pačių tokio „matavimo“ vienetų. Akivaizdu, kad tokios sąvokos kaip „didelis“ ir „mažas“, „žymus“ ir „nežymus“ labai abstrakčios, reliatyvios. Apie vieno ar kito reiškinio kokybę įmanoma spręsti tik lyginant ir pasitelkiant empiriškai „išgaunamus“, „pasveriamus“ rodiklius. Iš čia kyla antroji problema, lemianti mūsų ¡žvvalgų subjektyvumą dèl ịvairių išlygų. Mat pats šio straipsnio koncepcijos igyvendinimas, šiandienos akimis žiūrint, neišvengiamai turètų remtis sociologinių visuomenès apklausų duomenų analize. Deja, pirmajjị nepriklausomybės dvidešimtmetị nugyvenusioje Lietuvoje tokie tyrimai nebuvo atliekami. Gyventojų nuotaikas savo ataskaitose fiksavo tik slaptas žinias rinkusių vidaus reikalų ir krašto apsaugos sistemų 
pareigūnai. Tokio pobūdžio medžiagos Lietuvos centrinio valstybès archyvo fonduose gana gausu, tačiau tų dokumentų informacija, vertinant jų išsamumą, - labai ịvairi, o karo padèties klausimu dažnai ypač fragmentiška. Cenzūruota to meto periodika taip pat nèra pernelyg iškalbinga tyrèjui. Kiti šaltiniai mus dominančia tema - atsiminimai, dienoraščiai - ganètinai subjektyvūs, dažnai labiau atspindintys paskiros asmenybės nuomonę, nei platesnių visuomenės sluoksnių požiūrị. Juolab kad XX a. 3-4 dešimtmečiu Lietuvos visuomenè buvo nevienalytis, sluoksniuotas darinys ${ }^{10}$, veikiamas nemažų vidaus socialinių, politinių ir tautinių prieštaravimų ${ }^{11}$. Didžiausią ịtaką to darinio būsenai turèjo jo lietuviškasis branduolys, apèmęs apie 80 procentų visų gyventojų daugiausia katalikų tikejjimo, šiek tiek raštingų smulkių ir vidutinių ūkininkų. Etninių lietuvių miestiečių - pramonès darbininkų, verslininkų, inteligentu grupes (kiekviena atskirai) sudare tik po kelis procentus nuo bendro piliečių skaičiaus. Tautinès mažumos - žydai, lenkai, vokiečiai ir provokiškai orientuoti Klaipèdos krašto lietuvninkai - iš esmès gyveno savo atskirą visuomeninį gyvenimą, jų santykiai su lietuvių dauguma ir jos sukurta valstybe visą nepriklausomybès dvidešimtmetị buvo ganètinai šalti, o kai kuriais etapais - net ir aiškiai komplikuoti. Lètą, menkai rezultatyvią tautinių mažumų integraciją, taip ir nepasibaigusią tikrai darnios, konsoliduotos Lietuvos piliečių bendrijos susiformavimu, lèmé abiejų sąveikavusių pusių tarpusavio nepasitikejjimas, politinių orientyrų ir preferencijų skirtumai. Lietuvos lenkai dairèsi ị Varšuvą ${ }^{12}$, vokiečiai ir

$101937 \mathrm{~m}$. sausio 1 d. duomenimis, Lietuvoje (be Vilniaus krašto) buvo apie 2,5 mln. gyventojų. Iš jų 80,6 proc. sudare lietuviai, 7,1 proc. - žydai, 4,1 proc. - vokiečiai, 3 proc. lenkai, 2,4 proc. - rusai. 80,5 proc. gyventojų buvo katalikai, 9,5 proc. - evangelikai liuteronai. Miestuose gyveno tik 16 proc. visų piliečių. Žr.: Vadovas po Lietuvą. Red. P. Barkauskas, A. Vabalas. Kaunas, 1938, p. 16-17.

${ }_{11}$ Laurinavičius, Č. Valstybès visuomenès politika // Lietuvos istorija, t. X, d. I (Nepriklausomybe 1918-1940). Vyr. red. Č. Laurinavičius. Vilnius, 2013, p. 15-17; Laurinavičius, Č. Laimèjimai ir atsilikimo apraiškos // Ten pat, p. 330-336.

12 Apie lenkų padètị Lietuvoje žr.: Buchowski, K. Retorsijos ịkaitai (Lenkai Lietuvos Respublikoje 1918-1940 metais). Darbai ir dienos, t. 34, Kaunas, 2003, p. 49-101. 
klaipediečiai - i Berlyną ${ }^{13}$, žydai jautèsi išstumti iš politinès sferos, viešojo administravimo sektoriaus, todèl gana didelè jų jaunesniosios kartos dalis „užsikrète“" Maskvos Kominterno idejomis ${ }^{14}$. Tačiau valstybès vairą laikantys lietuvių politinio elito atstovai nebuvo linkę labiau paisyti mažumų pageidavimų, apskritai puoselejo viltis kuo greičiau ir kuo labiau sulietuvinti Lietuvą. Dèl to „kitataučiai piliečiai“ kiekvieną lietuvių valdžios inicijuojamą šalies vidaus gyvenimo policinès kontrolès stiprinimo žingsnị (glaudžiai susijusi su karo padèties režimu) daugeliu atvejų galejo traktuoti kaip sąmoningas, nors ir korektiškai motyvuotas, pastangas dar labiau suvaržyti „nelojalių mažumų saviraišką.

Tad apibendrinti Lietuvos visuomenès, kaip visumos, požiūrị i vieną ar kitą reiškinị valstybejje galima tik su nemažomis išlygomis, pritaikant gerokai supaprastintą schemą. Šiame straipsnyje kaip tik ir nueita šiuo keliu, Lietuvos visuomenès nuomonès pagrindine reiškejja laikant gausiausią jos dalị, apimančią „titulinès“ lietuvių tautos agrarinị sluoksnị. Iš jo buvo kilęs ir beveik visas to meto politinis šalies elitas.

Tokia ribota visuomenès samprata, viena vertus, gerokai susiaurina tiriamojo lauko horizontą, kita vertus, padaro labiau aprèpiamą tą gausią, nors ir nepakankamai informatyvią medžiagą, kuria tenka remtis atliekant tyrimą. Taigi, situacija ganètinai specifiška. Vis dèlto manytume, jog šaltinių ribotumas ir nepakankamas objektyvumas neturètų tapti tuo barjeru, kuris sustabdo istoriką, siekiantị iškelti vieną ar kitą probleminị klausimą, pabandyti i jị bent iš dalies atsakyti - jei ne „matematiškai preciziškai“, tai nors „humanitariškai - hipotetiškai“. Optimistiškai samprotaujant, bet kokia, kad ir iš duomenų trupinių sukonstruota, kad ir „silpnų vietų“ turinti analitiné pozicija, vis tiek labiau praveria duris $\mathfrak{i}$ problemos pažinimą, išaiškinimą, nei išankstinis dogmatiškas metodologinis nusistatymas, kad „košès iš kirvio neišvirsi“, „vežimo iš skiedros nepriskaldysi“, todèl to imtis net neverta.

13 Žr.: Žalys, V. Ringen um Idetität: Warum Litauen zwischen 1923 und 1939 im Memelgebiet keinen Erfolg hatte. Kova dèl identiteto: Kodèl Lietuvai nesiseke Klaipédoje tarp 1923-1939 m. Lüneburg, 1993; Jakubavičiené, I. Lietuvos vokiečių Kultūrverbando ryšiai su Vokietija 1933-1940 metais. Istorija, 2006, Nr. 64, p. 40-51; Jakubavičienè, I. Ar pagrịstai Lietuvoje vokiečių Kultūrverbandas buvo valstybès saugumo institucijų akiratyje 1933-1945 metais? Istorija, 2010, Nr. 2, p. 34-45.

14 Truska, L. Lietuviai ir žydai nuo XIX a. pabaigos iki $1941 \mathrm{~m}$. birželio. Vilnius, 2005, p. 129. 


\section{KARO PADĖTIES REŽIMO LIETUVOS RESPUBLIKOJE (1919-1939 M.) TURINYS IR EVOLIUCIJOS BRUOŽAI}

Prieš pradedant nagrinèti, kaip ilgalaikè karo padètis Lietuvos Respublikoje paveikè kariuomenès ịvaizdị visuomenès akyse, būtina pateikti pačius svarbiausius bendruosius duomenis apie šio teisinio-administracinio režimo turinị ir pristatyti esmines per dvidešimtmetị išryškëjusias jo raidos tendencijas.

Karo padètị laikinojoje sostineje Kaune ir keliose aplinkinèse apskrityse ịvedè Mykolo Sleževičiaus vyriausybè, $1919 \mathrm{~m}$. vasario $7 \mathrm{~d}$. prièmusi ir kovo pradžioje spaudoje paskelbusi specialų îstatymą, pavadintą Ypatingais valstybès apsaugos įstatais ${ }^{15}$. Tai nebuvo visiškai originalus teisès aktas - ji rengiant akivaizdžiai remtasi atitinkamais iš carinès Rusijos „paveldètais“ šaltiniais ${ }^{16}$. Karo padèties režimas, per vienus metus palaipsniui išstūmus bolševikus, bermontininkus ir sustabdžius lenkus, i̇sigaliojo visoje Lietuvos vyriausybei pavaldžioje teritorijoje. Ypatingi valstybès apsaugos įstatai Lietuvos kariuomenès karinès administracijos atstovams miestų ir apskričių karo komendantams - karo padèties laikotarpiu suteike plačius igaliojimus reguliuoti civilini gyvenimą, pajungti ji krašto gynybos poreikiams. Karo komendantūros galèjo kontroliuoti prekybą, materialinių ir darbo resursų naudojimą, asmenų judejjimą, nustatyti transporto prievoles, prižiūrèti viešąją tvarką, vykdyti spaudos cenzūrą, uždrausti susirinkimus. Tam pakako viešo privalomo karo komendanto ìsakymo. Už tokių įsakymų nevykdymą grèsè rimtos administracinès sankcijos - piniginès baudos, areštas, ištrèmimas, izoliavimas koncentracijos stovykloje arba net perdavimas kariniams teismams (laikinai sudaromam karo lauko arba nuolatiniam Kariuomenès teismui) ${ }^{17}$. Šie bylas nagrinè-

15 Ypatingi valstybès apsaugos įstatai. Laikinosios Vyriausybès žinios (toliau - LVŽ), 1919 kovo 5, Nr. 4-42. Šiek tiek atnaujinta jų redakcija, galiojusi visą paskesnị dvidešimtmetị, buvo paskelbta po mènesio. Žr.: LVŽ, 1919 balandžio 4, Nr. 5-55.

16 Žr.: Правила о местностях, объявленных состоявшими на военном положении // Свод законов Российской империи (В пяти книгах. Ред. И. Д. Мордухай-Болтовский, кн. 1, т. 2. С. Петербург, 1912, с. 170-174.

17 Išsamiai žr.: Stoliarovas, A. Lietuvos Respublikos karine justicija 1919-1940 m. Kaunas, 2014. 
jo supaprastinta, pagreitinta tvarka ir skelbdavo griežtus nuosprendžius. Už šnipinejjimą, sabotažą, kenksmingą agitaciją ir kitokią pagalbą priešui, taip pat už organizuotus kriminalinius nusikaltimus buvo numatyta mirties bausmè arba ilgi metai sunkiųjų darbų kalëjimo.

Karo padèties nuostatos, suspendavusios arba smarkiai apribojusios pagrindines pilietines laisves, aiškiai kirtosi su Vasario 16-osios deklaracijoje pateikta demokratinès Lietuvos vizija, ypač kai jų galiojimo trukmès ir sąlygų klausimas politiškai èmè darytis vis labiau neapibrèžtas ir komplikuotas. Vadinamuoju „Seimų laikotarpiu“ (1920-1926 m.) po karštų ginčų tarp valdžioje dominavusių krikščionių demokratų stovyklos ir kairiosios opozicijos (socialdemokratų ir tam tikrais epizodais valstiečių liaudininkų) Ypatingų valstybès apsaugos ịstatų nustatytų griežtų suvaržymų poveiki Lietuvos vidaus gyvenimui nuolat siekta optimizuoti. Dèl to XX a. trečiojo dešimtmečio pirmoje pusejje taikyta karo padèties ribojimo praktika, paremta teritoriniu ir instituciniu principu. Išimtinis režimas paliktas galioti tik ten, kur Krašto apsaugos ministerijos (KAM) nuomone, Seimui pritarus, tai buvo būtina. Karo padètis tada nuolat galiojo visose pietinėse ir rytinèse apskrityse arba tam tikruose jų valsčiuose, besiribojančiuose su Lenkijos užimta teritorija, t. y. išilgai „pafrontès“ - demarkacijos linijos, visoje geležinkelių zonoje ir kariuomenejje (tiek teritorijos apsaugos, tiek vidaus tvarkos požiūriu) ${ }^{18}$. Ypatingojo režimo sąlygomis tuo metu beveik nuolat gyveno ir laikinoji sostine Kaunas.

1926 m. antroje pusejje, Seime daugumą sudarius kairiajai koalicijai (valstiečiams liaudininkams, socialdemokratams ir tautinių mažumų atstovams), karo padètis Lietuvos Respublikoje pirmą kartą buvo visiškai atšaukta (išskyrus $1 \mathrm{~km}$ pločio juostą išilgai demarkacijos linijos) ${ }^{19}$. Tai padarè ryškų poveikị šalies visuomeniniam gyvenimui ir iš jo kylančios politinès veiklos (neretai nebrandžios, nepakankamai atsakingos, kartais net destruktyvios) plètotei, nes neliko griežtų susirinkimų rengimo, organizacijų veiklos ir spaudos leidybos kontrolès rèmų.

18 Žr.: Karo stovio panaikinimo įstatymas. $L V Z \check{Z}, 1920$, kovo 4, Nr. 20-255; Itstatymas karo stoviui įvesti. Vyriausybès žinios (toliau - VŽ), 1920, liepos 23, Nr. 41-430. Karo stoviui ìvesti įstatymas. $V Z \check{Z}, 1922$, rugsèjo 8, Nr. 105-823.

19 Karo stovio panaikinimo įstatymas. $V \check{Z}, 1926$, liepos 2, Nr. 242-1582. 
1926 m. antrosios pusès M. Sleževičiaus vadovaujamos kairiosios vyriausybės valdymo pusmetis, paženklintas karo padėties atšaukimo, prieštaringų žingsnių kadrų politikoje ir skirstant lèšas, Lietuvos kariuomenejje sukèlè didelị nepasitenkinimą, turèjusį lemiamą reikšmę sèkmingai gruodžio 17-osios karinio perversmo baigčiai, atvèrusiai kelią i valdžią tautininkams (Respublikos prezidento postą užèmusiam Antanui Smetonai, Ministrų Kabineto vadovu tapusiam Augustinui Voldemarui) ir jų greit eliminuotiems laikiniems sąungininkams krikščionims demokratams. Perversmo metu Lietuvoje iš naujo ịvesta karo padetis ${ }^{20}$ nebuvo kaip nors apribota ar atšaukta iki pat 1938 m. lapkričio. Iš pradžių ji atrodè visai pagrịsta, nes intensyviai „medžioti“ komunistai - jų sąmokslo užkardymas oficialiai laikytas tikrąja „tautinių jègų“ ivvkdyto perversmo priežastimi ${ }^{21}$. 1927-1929 m. šalis „kunkuliavo“, kaitinama politinių aistrų, kaskart vis išsiliejančių per kraštus nedidelèmis ginkluotomis avantiūromis. Šiuo požiūriu daugiausia rūpesčių kẻlè iš valdžios pašalinti kairieji, ypač socialdemokratai, kurie, siekdami revanšo, bande organizuoti pučus, diversijas ir tuo tikslu atvirai naudojosi didžiausio tuometinio Lietuvos priešo - Lenkijos parama ${ }^{22}$. Be to, greitai ,juoda kate““ perbėgo tarp krikdemų ir tautininkų, galiausiai nuo pastarųju atskilo A. Voldemaro šalininkai, patys nedelsdami èmęsi regzti planus, kaip jèga pakeisti, jų nuomone, pernelyg nuosaikią vyriausybę $e^{23}$. O kur dar ketvirtajame dešimtmetyje vis stiprejjęs vokiečių revanšizmas Klaipèdos krašte, neramumai Suvalkijoje, bendros opozicinès "ašies“ formavimasis ${ }^{24}$. Visos šios aplinkybès daugiausia lèmé tai, kad per beveik keturiolika prezidento A. Smetonos autoritarinio valdymo metų, pasibaigusių tyliu Lietuvos nepriklausomybès praradimu, šalis gyveno ypatingojo teisinio

\footnotetext{
20 Karo stovio įvedimo aktai. $V \check{Z}, 1926$, gruodžio 31, Nr. 242-1582.

21 Ivykių eigoj. Lietuva, 1926, gruodžio 20, p. 1.

22 Čepas, R. Plečkaitininkai. Vilnius, 2000, p. 36-109. To paties. Ivadas // Mirties dekretas demokratijos gynejams, arba kaip karo lauko teismas pasmerke mirti dr. J. Pajauji, E. Tornau ir J. Žemaitị. Sud. R. Čepas. Vilnius, 2001, p. 12-17.

23 Plačiau žr.: Rudis, G. Augustinas Voldemaras ir voldemarininkai // A. Voldemaras. Pastabos saulèlydžio valandą. Vilnius, 1992, p. 18; Povilaitis, A. Neramios dienos. Sukilimai Lietuvoje nuo Nepriklausomybès atgavimo iki šiu mety [1939] sausio 1 d. Kaunas, 1996, p. 17.

24 Žr.: Rudis, G. Jungtinis antismetoninès opozicijos sąūdis 1938-1939 m. Lietuvos istorijos metraštis. 1996 metai. Vilnius, 1997, p. 182-215.
} 
administracinio režimo sąlygomis. Tačiau tai nereiškia, kad karo padèties (dokumentuose - „karo stovio“) atšaukimo arba pakeitimo kita Vidaus reikalų ministerijos struktūrų administruojama ypatingosios padèties forma ${ }^{25}$ klausimas politiniuose ir kariniuose Lietuvos sluoksniuose nebuvo keliamas. Iš tiesų vyriausybès užkulisiuose retkarčiais ji tekdavo prisiminti ir apie tai diskutuoti. Gana intensyviai ịvairios galimybès svarstytos 1928-1931 m. ${ }^{26}$ Tada net ir viešai - spaudoje - pažerta šiokių tokių atsargių pažadų ${ }^{27}$. Vis dèlto jų dèl neišsenkančio ịvairaus plauko opozicijos nerimastingumo taip ir nesiryžta savo valia išpildyti. Panašiai baigèsi ir 1936-1937 m. vèl tarsi pagyvejjusios diskusijos ypatingosios padèties režimo transformacijos tema, nors jau buvo spèta parengti netgi konkrečių teisès aktų projektų ${ }^{28}$. Kita vertus, ketvirtąji dešimtmetị karo padèties režimas buvo gerokai patobulintas, prièmus ịvairių Ypatingu valstybės apsaugos ịstatų pakeitimų ir papildomų ịstatymų, daugiausia skirtų karo komendantų viešojo gyvenimo kontrolès funkcijų naštai palengvinti (žymią jų dalị perleidžiant VRM sistemai) ${ }^{29}$, stiprinant užsienio

25 Turimas omenyje „Sustiprintos valstybès apsaugos metas“, kurị reglamentuojantis isstatymas pradètas svarstyti dar $1922 \mathrm{~m}$., o priimtas $1925 \mathrm{~m}$. Žr.: Steigiamojo Seimo darbai (toliau - SSD). 1922, rugpjūčio 3, 236 pos., p. 63; Seimo stenogramos. Antrasis Seimas (toliau - SSAS). 1924, gegužès 6, 93 pos., p. 12-15; SSAS, 1925, gegužès 19, 182 pos., p. 14; Sustiprintos apsaugos ịstatymas. VZ̆, 1925, birželio 13, Nr. 194-1318.

${ }^{26}$ Kuodys, M. Varniai, Dimitravas, Pabradè: Koncentracijos ir priverčiamojo darbo stovyklos Lietuvoje 1927-1940 m. Vilnius, 2007, p. 109-110; Lietuvos Respublikos apskričuu viršininkų suvažiavimo $1930 \mathrm{~m}$. spalio $31 \mathrm{~d}$. posėdžio protokolas. Lietuvos centrinis valstybés archyvas (toliau - LCVA), f. 394, ap. 2, b. 1229, l. 189.

27 Karo stovis dar nenuimamas. Lietuvos ūkininkas, 1929 gegužès 3, p. 14; Valstybès apsaugos ịstatymas. Lietuvos ūkininkas, 1931 gegužès 28 d., p. 1; Lietuvos policija 1918-1928. Red. I. Tamašauskas. Kaunas, 1930, p. 416.

$281937 \mathrm{~m}$. vasario $5 \mathrm{~d}$. Valstybès Tarybos raštas ministrui pirmininkui J. Tūbeliui. LCVA, f. 923 , ap. 1, b. $1087,1.196 ; 1937$ m. sausio 13 d. Nepaprastosios padèties ịstatymo projektas ir priedai. LCVA, f. 923, ap. 1, b. 1087, 1. 149-202; 1938 m. spalio 15 d. Tautai ir valstybei saugoti istatymo papildymo projektas. LCVA, f. 923, ap. 1, b. 1087, 1. 1-10. Lietuvos Respublikos Seimo stenogramos, V paprastoji sesija (1938 09 01-1938 12 31), 96 pos., p. 45 .

${ }^{29}$ Susirinkimų ir pramogų ịstatymas. VŽ, 1932 rugsèjo 5, Nr. 390-2688; Spaudos ịstatymas. VZ̆, 1935, lapkričio 16, Nr. 510-3538; Draugijų ịstatymas. VZ̆, 1936, vasario 1, Nr. 522-3226; Taisyklès draugijų i̇statymui vykdyti. VZ̆, 193610 08, Nr. 553-384; Draugijų i̇statymo pakeitimas. VŽ, 193611 12, Nr. 557-3870; Sustiprintos apsaugos įstatymo pakeitimas. VŽ, 193611 12, Nr. 557-3873. 
šalių remiamų antivalstybinių organizacijų persekiojimą ${ }^{30}$.

Teisès aktų tobulinimas ir pildymas, atsakomybès sričiu perskirstymas buvo veiksmingas optimizuojant karo padèties režimą, paprastinant jo administravimą. Taip racionaliai viską sutvarkiusi, šį efektyvų vidaus gyvenimo kontrolès instrumentą Lietuvos vyriausybẻ būtu galëjusi naudoti ilgai. Tačiau susidurta su rimtu išoriniu pasipriešinimu. Vokietijai agresyviai paspaudus, $1938 \mathrm{~m}$. lapkričio $1 \mathrm{~d}$. karo padeti prezidentas A. Smetona atšaukè ne tik Klaipèdos krašte (to konkrečiai reikalavo naciai), bet - desperatiškai gelbedamas prestižą - ir visoje Lietuvoje ${ }^{31}$. Kad tai buvo padaryta labai nenoriai, greitai parodè paskesni autoritarinès valdžios žingsniai. 1938 m. gruodžio 10 d. po Kaune vykusio patriotinių opozicinių jègų sujudimo iš pradžiu laikinojoje sostineje ${ }^{32}$, o po Klaipèdos krašto praradimo (1939 m. kovo $22 \mathrm{~d}$.) ir visoje šalyje $\mathrm{e}^{33}$ buvo įvestas VRM administruojamas policinis režimas - Sustiprintos apsaugos metas. Jo nauja redakcija, suderinta su karo padèties, oficialiai pradètos vadinti „valstybès gynimo metu“, nuostatomis, buvo integruota ị 1939 m. gegužę paskelbtą Nepaprastojo meto įstatymą ${ }^{34}$. Pažymètina, kad tų pačių metų spalio 27 d. Lietuvos kariuomenei įžengiant ị Sovietų Sąjungos pagal Savitarpio pagalbos sutarti perduodamą Vilniaus kraštą, šioje teritorijoje buvo įvestas valstybės gynimo metas ${ }^{35}$, o visose kitose šalies apskrityse liko galioti „sustiprinta apsauga“. Ir vis dèlto, nepaisant visų šių pertvarkų, ypatingasis režimas Lietuvoje esmingai nepasikeite - tad jị galima analizuoti ir vertinti kaip vientisą, pastovų reiškinị.

\footnotetext{
30 Čia pirmiausia turima omenyje prieš plečkaitininkus nukreiptas $1929 \mathrm{~m}$. Organizacijų, sudarytų okupuotoje Lietuvoje ir svetimose valstybėse, dalyviams ir jų padejejams bausti istatymas (VŽ, 1929, birželio 25, Nr. 304-2033) ir $1934 \mathrm{~m}$. Tautai ir valstybei saugoti ịstatymas (VŽ, 1934, vasario 8, Nr. 437-3044), sudaręs sąlygas veiksmingai persekioti Klaipèdos krašto nacionalsocialistus.

31 Žr.: Kuodys, M. Lietuvos visuomenès reakcija ị karo padèties atšaukimą šalyje $1938 \mathrm{~m}$. lapkričio 1 d. Istorija, t. LXXXIII, 2011, p. 37-45.

32 Respublikos Prezidento aktas Nr. 1651. VŽ, 1938, gruodžio 10, Nr. 627-4504.

33 Respublikos prezidento aktas Nr. 374. VZ̆, 1939, kovo 22, Nr. 637-4643.

${ }^{34}$ Nepaprastojo meto įstatymas. VŽ, 1939, gegužès 10, Nr. 644-4701.

35 Respublikos prezidento aktas Nr. 1260. VŽ, 1939, spalio 27, Nr. 671-4950.
} 


\section{ŽVILGSNIS İ KARO PADĖTIES REŽIMĄ IR JO RYŠI SU KARIUOMENE IŠ „EILINIO PILIEČIO“ PERSPEKTYVOS}

Pristačius karo padèties režimo reglamentaciją ir politines aplinkybes, lèmusias tam tikrą jo evoliuciją, galima nuosekliai pereiti prie kur kas sudètingesnio probleminio klausimo: kiek ta išimtinè, nuolatine virtusi Ypatingų valstybės apsaugos ịstatų nustatyta tvarka jausdavosi paprastų Lietuvos piliečių kasdieniame gyvenime, ar apskritai ji buvo suvokiama kaip atskiras, specifinis reiškinys, galiausiai ar visada ji tiesiogiai sieta su kariuomene?

1919 m. pirmoje pusëje Kauno kontroliuojamose apskrityse pasirodžiusius lietuviškos karinès administracijos skelbimus apie ịvedamą karo padètị visuomenè sutiko gana ramiai - ịvairūs kontekstiniai šaltiniai rodo, kad tai netapo išskirtiniu i̇vykiu. Vyko Nepriklausomybès kovos, o karas pafrontès zonos ar slegiančios, brutalios užnugario okupacijos pavidalu tęsėsi ketvirtus metus. Krašto žmonès, kurių beveik aštuoniasdešimt procentų sudare lietuviai - beveik neraštingi žemdirbiai, religingi katalikai, iki tol jau buvo patyrę ịvairių išbandymų ir negandų, todèl $\mathfrak{i}$ visokius viena kitą keičiančių valdžių potvarkius reaguodavo su stojiška apatija. Karo padèties, kaip teisinio instituto, pobūdis šiek tiek praprususiems caro kariuomenejje tarnavusiems arba visuomeniškai aktyvesniems ūkininkams greičiausiai buvo daugmaž suvokiamas. Su šiuo reiškiniu teko susidurti net kelioms lietuvių kartoms, išgyvenusioms $1863 \mathrm{~m}$. sukilimą ir vèlesnius suvaržymų dešimtmečius ${ }^{36}$. Ypač issimintinas turëjo būti 1905 m. revoliucijos Rusijos imperijoje slopinimas ${ }^{37}$. Karo padètimi pagrịstos represijos tada plačiai taikytos ne tik kaimyninèse latvių žemėse, bet ir Suvalkų gubernijoje, kuriai priklausẻ lietuviškoji Užnemuné $^{38} .1914 \mathrm{~m}$. vasarą prasidèjęs Pirmasis pasaulinis karas Lietuvą visais

\footnotetext{
36 Andriulis, V., Maksimaitis, M., Pakalniškis, V., Peškaitis, J. S., Šenavičius, A. Lietuvos teisés istorija. Vilnius, 2002, p. 283.

37 Поликарпов, В. Д. Военная контрреволюиия в России 1905-1917. Москва, 1990, c. 61-62.

38 Šenavičius, A. Lietuviškos Užnemunès valdymo teisė (1795-1915 m.). Lietuvos aukštujų mokykly mokslo darbai, Istorija, LIV, 2002, p. 50.
} 
atžvilgiais pavertė karo padèties zona ${ }^{39}$. 1915-1918 m. kaizerinė okupacija taip pat rèmèsi karinio administravimo principais ${ }^{40}$. Paskui Lietuvos vyriausybė ịvedè „savo“ ypatingąji režimą. Taigi, iš esmès iki pat $1920 \mathrm{~m}$. Lietuvos žmonès nebuvo patyrę, ką reiškia laisva pilietinè saviraiška demokratinès santvarkos sąlygomis. Būtent tai, o ne policijos ar karinès administracijos diktatas, kurio praeityje būta daug ir visokio, visuomenei tapo tikra naujove, savotišku iššūkiu. Deramai, atsakingai naudotis šios situacijos sukurtomis galimybėmis dauguma visuomenès nelabai sugebejjo, nes neturejo patirties. Reikejo laiko pilietinei brandai pasiekti, pasijusti tikrais savo valstybès šeimininkais. Dèl to ir besikuriančios Lietuvos valdžios institucijos, nelabai pasitikèdamos „liaudimi“, nenorejo visiškai atleisti kontrolès varžtų, bandyti pernelyg sparčiai keisti paveldètų politinès kultūros tradicijų.

I Lietuvos krašto apsaugos struktūrų igyvendinamą karo padėties režimą, kaip i̇ vientisą ir pastovią šalies administravimo sistemą, gyventojai èmé žvelgti maždaug 1919 m. pabaigoje, kai jaunos valstybès būsena, pajègus apsiginti nuo bolševikų ir bermontininkų, tarsi ir stabilizavosi.

Apibendrinant plačiame memuarinių šaltinių masyve glūdinčią informaciją galima teigti, kad savo - lietuvišką - karinę administraciją, nepaisant pasitaikydavusių sudètingesnių situacijų, platieji visuomenès sluoksniai vertino gana supratingai. Pirmiausia todèl, kad ankstesnis svetimųjų jungas slègè nepalyginamai baisiau. Be to, tam nemažą reikšmę turejo ir vidiniai patriotiniai motyvai, stiprejantis bendrumo jausmas. Juk daugelio šeimų jauni vyrai tarnavo savanoriais kuriamoje Lietuvos kariuomeneje arba buvo i ją mobilizuoti. Galiausiai su savo pačių apginta valstybe sietos teisingesnès, šviesesnès ateities viltys. Paprastiems žmonèms imponavo, kad jie, kaip niekada iki tol, galèjo ị kariuomenès atstovus kreiptis lietuviškai ir netgi jausti tam tikrą tarpusavio supratimą, pagrịstą bendra agrarine kilme, pasaulèžiūra ir tradicijomis. Pirmaisiais Lietuvos nepriklausomybès metais karo komendantai buvo vienintelè

3919140720 Именной высочайший указ об объявлении некоторых месностей империи на военном положении // Законодателные акты вызваные войною 19141915 2. г. Ред. О. И. Авербах. Петроград, 1916, с. 15-16.

40 Apie kaizerinę okupaciją konceptualiai žr.: Gimžauskas, E., Pirmasis pasaulinis - Didysis „tautų vadavimo“ karas. Ką jis reiškė Lietuvai // Lietuvos istorija, t. X, d. 1 (Nepriklausomybė 1918-1940). Red. Č. Laurinavičius. Vilnius, 2013, p. 23-94. 
tikrai patikima ir veiksminga vyriausybès atrama šalies regionuose. Tai lèmé ne tik dideli Ypatingų valstybès apsaugos ịstatų suteikti igaliojimai, bet ir kadrų kokybè. Komendanto pareigas daugiausia eidavo pakankamai išsilavinę, tvirto būdo, patyrę - šilto ir šalto matę - karininkai.

Tačiau besikuriančioje apskričių ir ypač valsčių savivaldoje bei milicijoje tada tikrai netrūko amoralios padermès asmenų, dèl kurių prieštaringos ar net aiškiai nusikalstamos veiklos nukentẻdavo tiek piliečiai, tiek valstybès autoritetas ${ }^{41}$. Prigriebti savivaliautojus neretai pajègdavo tik karo komendantai. Ne mažiau sèkmingai jie kovojo ir su pirmaisiais Lietuvos Respublikos gyvavimo metais gana plačiai siautusiomis nuožmiomis plèšikų gaujomis. Dèl viso to kaimiškose vietovèse žmonès ị karo komendantus žiūrèdavo su pagarbia baime - žinodavo, kad gali būti griežtai nubausti už ịsakymo neįvykdymą, bet kartu pagrịstai jausdavosi būsią ginami ne tik nuo galvažudžių iš miško, bet ir nuo ịkyriai duoneliaujančių milicininkų. Oficialūs duomenys rodo, kad iš visų tuometès Lietuvos jejgos struktūrų atstovų karo komendantais skųstasi mažiausiai $^{42}$. Vis dèlto tai nereiškia, kad šių karininkų teisètai, be esminių procedūrinių pažeidimų, vykdytos funkcijos nekeldavo visuomenei nepasitenkinimo. Ūkininkus labai vargino komendantų reikalavimai juos arba jų nurodytus pareigūnus be atlygio ar pusvelčiui, atsitraukus nuo lauko darbų, kur nors nuvežti nuosavu vežimu su pakinkytais arkliais. Erzino ir kitos darbo prievolès, taip pat persekiojimas už naminès degtinès varymą, patikrinimai, ieškant vagių, dezertyrų ar vengiančių mobilizacijos vyrų, judejjimo ir ūkinès veiklos suvaržymai tam tikrose vietose (pavyzdžiui, geležinkelio ${ }^{43}$ ir pafrontès zonose). Tiesa, vaikščiojimo ir važinèjimo tamsiu paros metu apribojimus, ypač kaimiškose vietovėse, vos tik

${ }^{41}$ Karo komendantų suvažiavimo $1921 \mathrm{~m}$. rugsėjo 20-24 d. protokolai. LCVA, f. 483, ap. 7, b. 87, 1. 5, 7, 10-11.

42 Steigiamojo Seimo skundų komisija 1920 m. gavo 324 skundus. Daugiausia skųstasi Vidaus reikalų ministerija (VRM) ir Krašto apsaugos ministerija (KAM). Iš 60 skundų, tekusių VRM, 38 skųstasi milicijos veiksmais, 17 - apskričių viršininkais. Iš kiek daugiau nei 60 skundų, tekusių KAM, 37 reikštas nepasitenkinimas kariuomene ir žvalgyba, 12 karo komendantais. Žr.: SSD, 1921, sausio 28, 58 pos., p. 564.

${ }^{43}$ Plačiau žr.: Kuodys, M. Karo padèties Lietuvos geležinkelių zonoje funkcionavimas 1919-1926 m. Karo archyvas, t. 23. Vilnius, 2008, p. 180-245. 
susidarydavo objektyvios galimybès, stengtasi kuo labiau sušvelninti ${ }^{44}$.

Karo komendantūrų ìvaizdị ūkininkų akyse būtų kur kas labiau sugadinęs jų nuolatinis ir tiesioginis dalyvavimas išieškant gyventojų ypač nemėgstamas rekvizicijas (žemės ūkio ir kitokios produkcijos paėmimas už fiksuotą, nelabai rentabilų atlygi kariuomenès reikmėms) ${ }^{45}$ ar organizuojant darbo prievoles. Tačiau tuo komendantams tekdavo užsiimti tik Nepriklausomybės kovų metu ir dažniausiai epizodiškai. Kita vertus, bendram požiūriui ị kariuomenę šis faktas tada neturèjo didesnès reikšmès, nes rekvizicijas taip pat vykdè kariai ir karo valdininkai, tik priklausantys kitam KAM generalinio štabo skyriui - Intendantūrai.

$\mathrm{XX}$ a. trečiojo dešimtmečio pradžioje Lietuvos miestuose, pirmiausia - laikinąja sostine tapusiame Kaune, gyventojų požiūris ỉ karo komendantą kaip kariuomenès ir plačiąja prasme ì valdžios atstovą buvo labiau komplikuotas nei kaimiškuose regionuose. Didelę dalị miestiečių sudarè kitataučiai - žydai, lenkai (ar lenkakalbiai), rusai (ir rusakalbiai), vokiečiai $^{46}$. Jie ị lietuvių aspiracijas sukurti tautinę valstybę iš pradžių žvelgè atsargiai, neretai šaltai, o kai kada ir priešiškai. Dèl to ir solidarumą su Lietuvos kariuomene, jos atstovais dažniausiai demonstruodavo paviršutiniškai - tik „iš reikalo“, vadovaudamiesi elementariu praktišku principu - lojalumas už ramybę ir saugumą. Pastarajji komendantas dažniausiai užtikrindavo, bet „ramybę“ suteikdavo ne visada, ypač jei jos reikejjo abejotiniems verslams plètoti. Esant karo padéčiai, komendantūra ne tik nurodinèdavo, bet ir savo pajègomis talkindavo milicijai, taip suaktyvindama, sustiprindama jos darbą. Toks bendradarbiavimas padejo efektyviau kontroliuoti prekybą, prekių vežimą, būstų paskirstymą, pasilinksminimo įstaigų ir visuomeninių organizacijų veiklą, saugoti valstybės turtą, užtikrinti saugumą nakties metu. Kaune karo komendantūra svariai prisidejo prie kovos su spekuliacija, nelegaliais verslais, viešosios tvarkos pažeidimais, buvusios tvirtovès fortų ir kitos infrastruktūros ar-

44 İsakymas Vietinès kariuomenès brigadai Nr. 25, 1920 rugsejjo 15 d. LCVA, f. 10, ap. 1, b. 9, 1. 28 .

45 Išsamiai žr.: Kuodys, M. Valstybės kūrimo kaina: Lietuvos visuomenè ir kariuomenès rekvizicijos 1919-1923 m. Karo archyvas, t. 25. Vilnius, 2010, p. 136-157.

46 Janauskas, P. Lietuviškas lūžis. Kalbų varžybos Kauno savivaldybẻje 1918-1928 metais. Darbai ir dienos, Nr. 34, 2003, p. 34. 
dymu $^{47}$. Suprantama, kad dèl to nukentèdavo tam tikros, tikètina, gana žymios, miestiečių dalies nelegali veikla. Vieniems tapdavo sunkiau ką nors pasisavinti, antriems - parduoti, tretiems - nusipirkti. Tai galejo kelti ir kèlè pasipiktinimą, skatino „skersai“ dèbčioti ị karinę administraciją, miliciją, kurios neva "trukdo gyventi“, neleidžia to ar ano, griežtai baudžia. Aišku, netrūko ir reikalaujančių „prigriebti“ bei „gerai papurtyti“ kainas keliančius vertelgas ${ }^{48}$. Tačiau apskritai miestietiško verslo pagundų ir galimybių verpetan įsisukusius žmones, ko gero, labiau būtų patenkinęs radikaliai liberalus valdžios ir piliečio santykis, kur valstybė (ar jos to meto sąlygomis pats galingiausias vietinis atstovas - karo komendantas) atliktų tik naktinio sargo nuo vagių ir plèšikų funkciją. Kita vertus, efektyvesnis sunkius kriminalinius nusikaltimus padariusių asmenų persekiojimas ir griežtesnis baudimas buvo bene geriausiai Lietuvos gyventojų (tiek miesto, tiek kaimo) vertinamas karo padèties režimo aspektas $^{49}$. Niekur neteko rasti svaresnių patvirtinimų, kad visuomenę būtų labai piktinęs toks „drakoniškas“ teisingumas.

Apskritai karo komendantūros vaidmuo šalyje reguliuojant ūkinius ir socialinius procesus iki ketvirtojo dešimtmečio pradžios tolygiai menko, kol tapo iš esmès nominalus. Tuo pat metu palaipsniui mažinta karo komendantų pareigu našta viešosios tvarkos palaikymo ir opozicinès politinès veiklos užkardymo srityse. Visa tai praktiškai tapo VRM sistemos prerogatyva - karinè administracija tik skirdavo baudžiamąsias sankcijas. Dèl to XX a. ketvirtajame dešimtmetyje išorinis kariškas karo padèties režimo atspalvis Lietuvoje gerokai nublanko. Panašu, kad ir i karo komendantus tada imta žiūrèti kaip i kažką, kas labiau susiję su policija, valdininkija, nei su ginkluotosiomis pajègomis. Galima manyti, kad smulkiam ūkininkui, nubaustam pinigine bauda, pavyzdžiui, už nelegaliai laikomą medžioklinị šautuvą, ar kokiam Kauno triukšmada-

47 Su tuo susijusius Kauno karo komendanto įsakymus ir kitus dokumentus žr.: LCVA, f. 1126, ap. 4, b. 211, 212, 214; Kauno apskrities archyvas (KAK), f. 219, b. 7.

48 Bružas, A., Petrauskas, C. Kova su brangenybe. Karys, 1922, spalio 19, Nr. 42, p. 503.

49 Vietinès kariuomenès brigados vado mjr. A. Merkio $1921 \mathrm{~m}$. rugsèjo $7 \mathrm{~d}$. raportas krašto apsaugos ministrui. LCVA, f. 384, ap. 2, b. 318, 1. 5. Kad griežta karo padeties tvarka apsaugo pilietị nuo „ivairių naktinių paukščių, kriminalistų“, teisėsaugos ir karinės administracijos atstovai nepraleisdavo progų pabrèžti ir bendraudami su žiniasklaida. Žr., pvz.: Kar. Rus. [P. Ruseckas]. Karo stovị ịvedus. Lietuvos ūkininkas, 1920, rugpjūčio 1, p. 1; Mūsų visuomenès tvarka ir rimtis. Rytas, 1927, balandžio 12, p. 2. 
riui nebuvo labai svarbu, jog administracinę bausmę jiems skyrė karo komendantas. Nubaustieji, tikètina, tai laikẻ abstrakčiai suvokiamos valdžios „ịvertinimu“ ir savo užslèptą nepasitenkinimą veikiausiai adresuodavo būtent jai, o ne konkrečiai Lietuvos kariuomenei kaip institucijai. Iš slaptų VRM ir KAM struktūrų agentūrinių pažymų gana akivaizdžiai matyti, kad visuomenès akyse kariuomenè pirmiausia asocijavosi su šalies gynyba nuo išorès priešų, su nepalenkiamu ryžtu išvaduoti Vilniaus kraštą, išsaugoti Klaipėdą, o ne su policinèmis funkcijomis.

\section{REAKCIJA İ KARO PADE்TIES REŽIMO IŠŠŪKIUS LIETUVOS KARIUOMENĖS REPUTACIJAI}

Nors per dvidešimtmetị karo padèties režimas Lietuvoje gerokai evoliucionavo (prisitaike prie taikaus civilinio gyvenimo sąlygų, atsisakius nebūtinų suvaržymų, prievolių), tapo tarsi savaime suprantama, plačiosios visuomenès nekvestionuojama duotybe ${ }^{50}$, juridiškai vis tiek liko išskirtiniu, pačiu stipriausiu, valstybės valdymo instrumentu, 19191939 m. galiojusiose konstitucijose numatytu taikyti tik rimtos grèsmès atveju ir ribotą laiką. Tikroveje pastarasis principas buvo aiškiai pažeistas, ir tai tapo tam tikru iššūkiu valstybès ir kariuomenès ịvaizdžiui. Šiame skyriuje kaip tik ir bus aptarta, kiek šią problemą reflektavo Lietuvos valdžia ir pati kariuomenè.

Politiniai šalies sluoksniai dèmesị ì karo padèties neigiamą poveikị valstybès ir kariuomenès reputacijai atkreipè anksti - jau 1920 m. pradžioje, rinkimų i Steigiamąji Seimą kontekste ${ }^{51}$. Tai, be abejo, skatino ir pati to meto visuomeninio gyvenimo atmosfera, paremta idealistinèmis demokratinès santvarkos kūrimo viltimis. Joms daug reikšmės teikè ir tuo laikotarpiu svarbų vaidmenị formuojant pirmųjų Lietuvos Respubli-

\footnotetext{
50 Antai dar 1929 m. pabaigoje oficiozas „Lietuvos aidas“ atvirai konstatavo, jog prie „karo stovio“ „mes iš dalies jau esame tiek pripratę, kad ramūs piliečiai jo esimo beveik nebepastebime“. Vidaus reikalai ir užsienio opinija. Lietuvos aidas, 1929, lapkričio 28, p. 1.

511920 m. vasario 17 d. Ministrų Kabineto posèdžio protokolas. LCVA, f. 923, ap. 1, b. $86,1.64$.
} 
kos vyriausybių politiką vaidinę valstiečių ir liaudininkų lyderiai - Mykolas Sleževičius ir Kazys Grinius. Šie politikai, nors patys, organizuodami Lietuvos gynybą, ir naudojosi karo padètimi, buvo tvirtai pasiryžę jos atsisakyti vos tik pavojus jaunai valstybei atslūgs ${ }^{52}$. Tuo jie ir jų atstovaujama politinè jèga aiškiai skyrèsi nuo dar kairesnès ir radikalesnès Lietuvos socialdemokratų partijos, kuri beveik be išlygų buvo prieš ne tik karo padètị, bet ir reguliariąją kariuomenę ${ }^{53}$. Karo padèties pagrịstumo klausimas Lietuvos seimuose XX a. trečiojo dešimtmečio pirmoje pusejje keldavo karštas diskusijas ${ }^{54}$. Jos turejjo įtakos Ypatingų valstybès apsaugos ịstatų galiojimo apribojimui teritoriniu ir instituciniu požiūriu. Tai galima vertinti kaip savotišką ištikimybès demokratijos principams demonstravimą - norą parodyti, kad pilietinès laisvès varžomos tik ten, kur to išvengti jokiu būdu neįmanoma, kad tokia yra kaina, kurią laikinai tenka mokèti už savo tautinès valstybès išsaugojimą. Iš daugelio krašto apsaugos, vidaus reikalų ministrų ir jų igaliotų atstovų kalbų seimuose ir susirašinejjimo matyti, kad „jejgos struktūros“ aiškiai rẻmè karo padèties, kaip instrumento stabilumui šalyje palaikyti, panaudojimą - nematė geresnių priemonių, kaip dar kitaip tai būtų galima padaryti ${ }^{55}$.

Po 1926 m. gruodžio $17 \mathrm{~d}$. valstybès perversmo šiai nuostatai beveik atvirai èmé pritarti jau ir pati šalies politinè viršūnè. Karo padètis autoritariniam prezidentui A. Smetonai padejo ịveikti niekaip pasiduoti nenorinčios įvairių pakraipų opozicijos periodiškai metamus iššūkius. Tačiau jis pats ir jo aplinka neabejotinai suprato (nors viešose kalbose tai pripažinti vengta), kad tokia situacija, kai valdžia nesijaučia tvirta ir,

52 Žr. pvz.: M. Sleževičiaus kalba Steigiamajame Seime. SSD. 1920, rugsèjo 15, 44 pos., p. 351 .

53 Mitrulevičius, G. Radikaliai demokratinès Respublikos vizija: Steigiamojo Seimo socialdemokratų frakcijos nuostatos priimant 1920 m. Laikinąją ir 1922 m. Nuolatinę Lietuvos Respublikos konstitucijas. Socialinių mokslų studijos, Nr. 6(3). Vilnius, 2014, p. 729. 54 Išsamiau žr.: Kuodys, M. Karo padèties klausimas Lietuvos seimuose (1919-1927 m.). Karo archyvas, t. 22. Vilnius, 2007, p. 219-291.

55 Vietinès kariuomenès brigados vado mjr. A. Merkio $1921 \mathrm{~m}$. rugsejjo $7 \mathrm{~d}$. raportas krašto apsaugos ministrui K. Žukui. LCVA, f. 384, ap. 2, b. 318, 1. 6; Generalinio štabo 1922 m. kovo 26 d. raportas krašto apsaugos ministrui B. Sližiui. Ten pat, 1. 5; Krašto apsaugos ministro B. Sližio $1922 \mathrm{~m}$. kovo 27 d. pranešimas ministrui pirmininkui E. Galvanauskui. Ten pat, 1. 16-20. 
siekdama išsilaikyti, kliaujasi tik išimtinėmis teisinėmis-administracinèmis priemonèmis, labai kenkia jos ịvaizdžiui ir savotiškai byloja apie legitimumo stoką ${ }^{56}$. Tai buvo ypač „nepatogu“ siekiant plètoti santykius su demokratinemis Vakarų valstybèmis (pirmiausia Didžiąa Britanija ir Prancūzija), taip pat bendraujant su gausia JAV lietuvių diaspora, kuri gruodžio 17-osios perversmą ir po to igyvendinamą politikos kursą daugiausia vertino kritiškai ${ }^{57}$. Galiausiai karo padètis Klaipėdos krašte nuolat tapdavo ir Vokietijos skundų tarptautinei bendruomenei pretekstu - net dar iki nacių atejjimo ị valdžią Berlyne ${ }^{58}$.

Dèl „vidaus auditorijos“ nuomonès Lietuvos valdžia labai nesijaudino, didesnių skrupulų neturèjo, todèl rafinuotesnių būdų, kaip pridengti nedemokratišką tikrovę, pernelyg ir neieškojo. Pasitenkindavo esamą padeti pagrindžiančiais konstitucijų keitimais ${ }^{59}$, propagandiniais moralais apie „susiklausymo“, drausmès svarbą, kraštui pasukus išganingu „tautinès linkmès“ keliu ${ }^{60}$. To iš pažiūros pakako. Dauguma gana pasyvių gyventojų pirmiausia rūpinosi savo ūkiniais - ekonominiais reikalais, o karo padètis tam iš esmès netrukdè (gal netgi priešingai - didino viešąji saugumą), tad stigo svaraus stimulo kilti platesniems protestams. Opozicinèms politinėms jejgoms atstovaujančių iškilių asmenybių kritiškos kalbos taip pat didesnio ilgalaikio poveikio visuomenei nepadarydavo, išskyrus kelis vidinių sukrètimų epizodus, tokius kaip 1930-1932 m. tau-

56 Vidaus reikalai ir užsienio opinija. Lietuvos aidas, 1929, lapkričio 28, p. 1; Lietuvos kariuomenès vado S. Raštikio ir krašto apsaugos ministro S. Dirmanto $1936 \mathrm{~m}$. spalio 17 d. raštas ministrui pirmininkui J. Tūbeliui. $L C V A$, f. 384, ap. 3, b. 485, 1. 195; Raštikis, S. Kovose dèl Lietuvos. Kario atsiminimai, fotograf. leid., t. 1. Vilnius, 1990, p. 408; Vyriausybè nori, kad visas kraštas tvarkytųsi normaliais įstatymais. Vidaus reikalų ministras pulk. Leonas apie vakar Seime svarstytus svarbius ịstatymus. Lietuvos aidas, 1938, spalio 16, p. 3.

57 Žr.: Skirius, J., Lietuviu visuomenininkas ir diplomatas Bronius Kazys Balutis (18801967). Vilnius, 2001, p. 335-334.

58 Naujos kiršintojų pastangos Klaipèdos krašte. Lietuvos aidas, 1930, birželio 30, p. 2; Gaigalaitè, A. Dr. Dovas Zaunius ir jo diplomatija ekonominių sunkumų Europoje laikotarpiu (1929 11 08-1934 06 12) // Lietuvos užsienio reikalų ministrai 1918-1940 m. Vilnius, 1999, p. 268.

59 Apie autoritarizmo principų konstitucionalizavimą žr.: Maksimaitis, M. Lietuvos konstituciju istorija (XX a. pirmoji pusè). Vilnius, 2005, p. 212-264.

60 Žr. pvz.: Smetona, A. I Tautą. Lietuvos aidas, 1931, lapkričio 26, p. 1; V., L. Naujomis gairèmis (1926.XII.17-1935.XII.17). Lietuvos aidas, 1935, gruodžio 17, p. 6. 
tininkų valdžios konfliktas su Bažnyčia ${ }^{61}$ arba 1935 m. Užnemunès ūkininkų streikas ${ }^{62}$. Bet tik pirmasis epizodas sietinas su labiau pastebimu plačiųjų visuomenès sluoksnių nepasitenkinimu karo padėtimi. Mat Katalikų akcijos aktyvą ir rèmèjus karo komendantai baugino naudodami visą savo represinių priemonių arsenalą ${ }^{63}$. Tokia praktika, net ir turint omenyje tuo metu egzistavusias labai kuklias žmogaus teisių apsaugos normas, amžininkams dažnai atrodydavo šokiruojančiai neadekvati. Juk katalikiškoji opozicija veikè pabrěžtinai taikiomis priemonėmis, jokių antivalstybinių tikslų nepuoselejo - protestavo tik prieš tautininkų politinị monopolị, visuomeninès veiklos varžymą. Tad nesunku suprasti, kodèl šiaip jau gana apolitiškas, inertiškas, bet tradiciškai religingas žemès ūkyje nuo aušros iki sutemos plušantis statistinis Lietuvos pilietis negalèjo nesipiktinti tuo, kad kai kurie gerbiami kunigai už savo „karštesnius“ pamokslus, moksleivių organizavimą turèjo stoti prieš Kariuomenès teismą, patriotiški ateitininkų lyderiai buvo gniuždomi piniginėmis baudomis, kamuojami areštais, išsiunčiami ị Varnių koncentracijos stovyklą arba ištremiami ị atokią apskritị. Žinios apie tai sulaukdavo neigiamo atgarsio ir užsienyje $\mathrm{e}^{64}$.

Itampai tarp tautininkų ir Bažnyčios per kelerius metus atslūgus, visuomenès požiūrị ị karo padètị ir ją administruojančias karines struktūras èmé veikti kitos aplinkybès. 1935 m. aukščiausią laipsnị pasiekè konfliktas su Vokietija - „pakvipo“ tikru karu ${ }^{65}$. Iš dalies kaip šio konflikto padarinys oficialiai vertintas ir Užnemunès ūkininkų streikas. Susidariusioje situacijoje ypatingos teisinès-administracinès priemonès Lietuvoje tiek vidaus auditorijai, tiek išorès stebètojams nebeatrodè tokios nenatūralios. XX a. ketvirtojo dešimtmečio pirmosios pusès KAM dokumentuose gana iškalbingai atsispindi karinès administracijos primygtinès rekomendacijos išlaikyti karo padeti Klaipėdos krašte, nes kitaip bent kiek prigesinti vis labiau ịsiliepsnojantị Vokietijos be perstojo kurstomą

\footnotetext{
61 Plačiau žr.: Truska, L. Antanas Smetona ir jo laikai. Vilnius, 1996, p. 240-247.

62 Ten pat, p. 219-225.

63 Kuodys, M. Karo padèties represinių priemonių panaudojimas prieš katalikiškąją opoziciją Lietuvoje 1930-1932 m. Soter, t. 47, 2013, p. 19-30.

64 Marius, K. Mūsiškių „katalikų“ „tiesos žodžiai“ užsieniuose. Lietuvos aidas, 1931, kovo 20, p. 5; Ten pat, 1931, balandžio 10, p. 3.

65 Žostautaitè, P. Hitlerininkų kèslai užgrobti Klaipédos kraštą. Vilnius, 1986, p. 119-124.
} 
nacizmo gaisrą, atrodé, visiškai neịmanoma ${ }^{66}$.

Nesiryžtant atšaukti karo padèties ar bent pakeisti jos pavadinimą ir administratorius taip, kad dingtų „nenormalios“, beprecedentès regione Lietuvos „gyvensenos“ pojūtis, neliko kito būdo, kaip tik tobulinti „iš vidaus“" patị ypatingąji režimą, užtikrinti jo sklandų, ekscesų netrikdomą funkcionavimą. Norint šị siekị kuo labiau priartinti prie tikrovès, reikejjo skirti ypatingą dèmesị karinès administracijos kokybei, tinkamų kadrų atsakingoms pareigoms eiti parinkimui ${ }^{67}$. Šia prasme politiné valdžia gana dèmesingai įsiklausydavo ị kariuomenès atstovų nuomonę.

Reikšmingiausias tarpininkas tarp vyriausybès ir karinès administracijos XX a. trečiojo dešimtmečio pirmoje pusèje buvo Vietinès kariuomenès brigados vadas. Šias pareigas tada ejjo mjr. Antanas Merkys, vèliau sèkmingai kopęs karjeros laiptais ir ją baigęs paskutiniojo nepriklausomos Lietuvos premjero poste ${ }^{68} .1927 \mathrm{~m}$. nuspręsta įsteigti specialią „karo stovio reikalų referento" pareigybę prie krašto apsaugos ministro ${ }^{69}$. Šj postą 1928-1939 m. užèmè didelę darbo patirtị Kauno miesto karo komendantūroje igijęs, plataus kultūrinio akiračio karininkas (Karių teatro organizatorius) plk. Vladas Braziulevičius. Apskritai, skiriant miestų, o ypač laikinosios sostinès ir Klaipèdos karo komendantus, daug reikšmès teikta jų asmeninėms savybėms - siekta, kad šie pareigūnai atrodytų solidžiai, autoritetingai, netaptų visuotinès neapykantos ar pajuokų objek$\mathrm{tu}^{70}$. XX a. ketvirtajame dešimtmetyje karinè administracija jau išties atitiko gana aukštus kompetencijos ir nepriekaištingo elgesio standartus. Neteko niekur rasti informacijos, kad kuris nors ilgiau savo pareigas ejjęs karo komendantas būtų igijęs plačiau pasklidusią „buko žandaro“

${ }^{66}$ Klaipedos krašto karo komendanto plk. ltn. R. Liormano 1931 m. gegužès 7 d. pro memoria. LCVA, f. 384, ap. 2, b. 376, 1. 74; 1933 m. liepos 4 d. Klaipedos krašto gubernatoriaus V. Gylio pranešimas ministrui primininkui. LCVA, f. 923, ap. 1, b. 1319, 1. 354.

67 A. Š-a [A. Šova?]. Divizijų štabų viršininkų ir apskričių karo komendantų suvažiavimas. Kardas, 1936, birželio 15, Nr. 12, p. 327.

$68 \check{Z}$ r.: Kasperavičius, A. Antanas Merkys - paskutinis ministras pirmininkas // Lietuvos Respublikos ministrai primininkai (1918-1940). Vilnius, 1997, p. 413-471.

691927 m. vasario 9 d. KAM aplinkraštis karo komendantams. LCVA, f. 384, ap. 3, b. 395, 1. 71 .

70 Apie komendantų paskyrimus ir tarnybos trukmę vienoje vietoje žr.: Vaičenonis, J. Lietuvos kariuomené valstybès politinio gyvenimo verpetuose (1927-1940). Vilnius, 2004, p. 200-209. 
ar korumpuoto administratoriaus reputaciją. Vyravo griežto, bet teisingo tvarkos saugotojo vaizdinys. Bendraudami su „sisteminès“ opozicijos šalininkais inteligentais, komendantai neretai nevengdavo pademonstruoti supratingumo, net tam tikro „liberalumo“. Tokių liudijimų galima užtikti ịvairių to meto kultūriniame gyvenime aktyviau besireiškusių žmonių atsiminimuose. Užtat visiškai priešingai karinès administracijos atstovai elgèsi su komunistais ir kitais tikrais valstybės ardytojais. Todèl nenuostabu, kad šių grupių atstovai labiausiai ir koneveikẻ karinę administraciją. Bene daugiausia pagiežos susilaukdavo Klaipèdos karo komendantas plk. Raimundas Liormanas. Šiuo atveju tai reikètų suprasti kaip jo principingumo ir atkaklumo pripažinimą, mat nacių veikèjai ir jų sukurstyti autonominès srities gyventojai, kiekviena proga „spjaudydami“ $\mathfrak{i}$ viską, kas lietuviška, sąmoningai eskalavo konfliktą, kad, teisėsaugai sureagavus $^{71}$, iškart galètų vaizduoti kankinius ir, Vokietijai „tarpininkaujant“, šmeižtų Kaune posėdžiaujančią centrinę šalies vyriausybę tarptautinėms institucijoms ${ }^{72}$.

Lietuvos visuomenei šie faktai net ir be papildomo patriotinio propagandinio „apdorojimo“ suteikdavo aiškų pagrindą solidarizuotis su savo vyriausybès politika, ją priešiškoje aplinkoje igyvendinančiais pareigūnais ir apskritai su visa duoti atkirtị išorinei agresijai besirengiančia kariuomene. Taigi, pats gyvenimas, pati to neramaus dvidešimtmečio ịvykių tèkmė neretai kur kas geriau nei politinių ir karinių viršūnių ne visai nuoširdžios pastangos pasitarnaudavo tam tikrai karo padèties režimo reabilitacijai piliečių akyse.

71 Apie Klaipedos krašto komendanto skirtas administracines sankcijas už lietuviškumo niekinimą gana reguliariai informuodavo spauda. Būdavo pateikiama konkrečių, emociškai „užkabinančių“ detalių. Žr. pvz.: Komendanto pabaudos. Lietuvos aidas, 1933, rugsėjo 20, p. 7.

72 Žr. pvz.: Völkischer Beobacher vèl èmè smarkiai pulti Lietuvą. Lietuvos aidas, 1935, sausio 22 , p. 4. 


\section{IŠVADOS}

1. Per du funkcionavimo Lietuvoje dešimtmečius, nepaisant kai kurių epizodinių eksperimentų (susiejimo su tam tikromis teritorijomis ir institucijomis), transformacijos bandymų, karo padèties režimo reglamentavimas žymiau nepasikeitè, tačiau gerokai nutolo nuo pirminès savo paskirties (trumpalaikè tvarkos palaikymo užnugaryje ir paramos kariuomenei telkimo karo veiksmų metu priemonè), ilgainiui virsdamas beveik vien policiniu visuomenès politinès raiškos kontrolés instrumentu. Dèl to visuomenè tokios „gyvenimo realybès“ neretai tiesiogiai netgi nebesiedavo su kariuomene.

2. Karo padèties režimo poveikis kasdieniam Lietuvos žmonių gyvenimui 1919-1939 m. akivaizdžiai kito. Pirmaisiais metais dèl ịvairių prievolių, ūkinių apribojimų, suvaržymų dažnokai kildavo nepasitenkinimas karine administracija ir kitais kariuomenès atstovais. Tačiau takoskyrai tarp jų ir visuomenès susidaryti neleido saugumo, autoritetingo galios instituto poreikis, taip pat tautiniai ir patriotiniai motyvai. XX a. ketvirtajame dešimtmetyje karo padètis trikdè tik politiškai angažuotų, aktyvių visuomenès narių saviraišką, visų kitų kasdienybeje ji tapo menkai pastebima, todèl nepasitenkinimo kariuomene iš esmès nekèlè.

3. Lietuvos politine viršūnè ir kariuomenès vadovybè suvoke ir pripažino nuolat veikiančios karo padèties daromą žalą savo ir šalies reputacijai, todèl reiškè norą ir net atsargius pažadus, tinkamoms sąlygos susidarius, iš esmès keisti situaciją. Tačiau dèl vidaus opozicijos aktyvumo, didejjančio išorinio spaudimo karo padètis iki pat $1938 \mathrm{~m}$. pabaigos nebuvo atšaukta. Kita vertus, dèta nemažai pastangų taip patobulinti kariuomenès administruojamą vidaus režimą, kad jis kuo mažiau trikdytu piliečių kasdienybę, nepatrauktų užsienio stebètojų dèmesio. Tai iš esmès pavyko pasiekti, ir kariuomenès įvaizdis labai nenukentejo.

Iteikta 2018 m. lapkričio 26 d. 


\title{
THE STATE OF WAR IN THE REPUBLIC OF LITHUANIA IN THE PERIOD OF 1919-1939 AND PUBLIC ATTITUDE TO THE MILITARY
}

\author{
Dr. Modestas KUODYS, \\ The Ninth Fort of Kaunas Fortress
}

Based on the sources and historiographical material, the article aims to evaluate how much and how the state of war lasting for twenty years, i.e. from 1919 to 1939, in the Republic of Lithuania affected the attitude of the society to the military. First, the article briefly presents general features of the regulation and administration of the state of war in Lithuania. Then, it analyzes the specific aspects of the particular situation that had the biggest influence on the daily life of the society and how it changed over time.

The analysis of historical materials shows that during the first years of independence, there were many instances of dissatisfaction with the military administration and other representatives of the military due to the broad range of obligations and economic restrictions. Nevertheless, the divide between them and the society was prevented by the need for security, authoritative body of power and national patriotic feelings. In 1930s, the state of war interrupted the self-fulfillment of politically motivated and active members of the society only, while others barely noticed it in their daily lives and, therefore, expressed no hostility towards the armed forces.

The Lithuanian political authorities and top management of the armed forces realized and acknowledged the damage to their reputation and that of the state caused by the continuous state of war. Consequently, they expressed a desire and even cautious promises to change the situation under appropriate conditions. However, due to the active opposition and increasing external pressure, the state of war was not canceled up to the end of 1938. Nevertheless, considerable efforts were made to improve the internal regime administered by military authorities to avoid causing unreasonable problems to the residents and resenting foreign observers. 